\title{
DOUBLE-BLIND EVALUATION OF DIAZEPAM FOR PREMEDICATION
}

\author{
Alden B. Dobkin, M.D., Jacob S. IsRael, M.D., \\ Wiluiam Evers, M.D., and Christina M. Bisset, R.N."
}

Diazepam (Valium ${ }^{\circledR}$ ) is currently under investigation for use in a broad range of applications, particularly in anaesthesia, including the parenteral administration for direct current counter-shock for conversion of cardiac arrhythmias, and a variety of endoscopic procedures. ${ }^{1-12}$

The most useful area appears to be that for premedication because equanimity may be induced in tense, anxious patients without causing marked drowsiness, respiratory depression, or instability of blood pressure and pulse rate, especially in children, poor-risk patients, and elderly patients.

Diazepam was synthesized by Sternbach and Reeder. Its pharmacology was studied by Randall and his associates, ${ }^{13,14}$ who showed that it had anticonvulsant and muscle relaxant properties, depressed the electrical activity of the cerebral cortex and the limbic system, and had a marked taming effect without causing toxic abnormalities in the parenchymatous organs. Special studies by Himwich of the effect on the amygdala and hypocampus in the limbic system explain in part how diazepam may depress memory, reduce psychomotor activity, and suppress aggressive behaviour. ${ }^{15}$

This study was undertaken to determine the efficacy of this agent as premedication for patients scheduled to undergo elective major abdominal operations with inhalation anaesthesia.

\section{METHOD}

Identical capsules were prepared containing $10 \mathrm{mg}$ diazepam, $100 \mathrm{mg}$ secobarbital, and an inert placebo (lactose) to be used for oral administration the evening before operation. Similarly, vials were prepared containing diazepam ( $5 \mathrm{mg} / \mathrm{ml})$, secobarbital $(50 \mathrm{mg} / \mathrm{ml})$, and a solution containing the placebo. A random-number table was used to assign the three preparations to a list of 450 consecutive numbers. The code was deposited in the hospital pharmacy until the study was concluded and the data analysed, so that no one involved in the study could identify the drugs.

In the evening, following preanaesthetic rounds, consenting adult patients, who were scheduled for an elective major abdominal operation under general anaesthesia, were assigned premedication by the consecutive number. The capsule was administered by the duty nurse at 9 PM. In each case, orders were written to administer a $100 \mathrm{mg}$ capsule of secobarbital orally if the pationt was

-Department of Anesthesiology, State University Hospital, State University of New York, Upstate Medical Center, Syracuse, New York. 
not asleep within a reasonable time (one to two hours) after receiving the coded medication.

The following morning, one hour before scheduled surgery, $2 \mathrm{ml}$ of the same drug, according to the code number, was administered to the patient intramuscularly by a staff physician, along with either $0.3-0.6 \mathrm{mg}$ atropine or $0.2-0.4 \mathrm{mg}$ scopolamine from a separate syringe.

A questionnaire form was completed for each patient by a nurse specially trained for this work. She obtained information from the patient's chart and from the anaesthesiologist assigned to the case. She also interviewed the patient just before induction of anaesthesia and the attending anaesthesiologist following induction of anaesthesia. Finally, she followed the patient's postoperative course. The day following surgery, the patient was again interviewed by the nurse and the questionnaire was completed and checked for all data required. The protocol form used was the same as that previously reported for similar studies. ${ }^{16-10}$

All anaesthetics were supervised directly by the authors and each patient had the same induction procedure - intravenous gallamine and thiopental, hyperventilation with oxygen, and oral intubation, followed in the majority of cases by maintenance with a halogenated anaesthetic and nitrous oxide.

At the conclusion of the study, all the information on the protocol sheets were tabulated, transferred to IBM cards, and analysed statistically, employing the chisquare test and $p$ values. The code was then revealed.

\section{Results}

In all statistical analyses shown, a chi-square value equal to or greater than 6.0 indicates a significant difference in effect of treatment at the 0.05 or less probability level. Table I summarizes the distribution of the 450 patients who participated in this study according to their sex, age, physical state, time of sedation before induction of anaesthesia, amount of thiopentone administered for induction, and primary maintenance agents. The three treatment groups of patients were statistically virtually identical, indicating that the randomization procedure was reliable.

\section{Supplementary medication (Table II)}

Induction of sleep the night before surgery occurred in almost 90 per cent of the patients who received diazepam without supplementation, whereas the placebo and secobarbital were apparently effective in less than 80 per cent. Statistical analysis showed that diazepam was significantly more reliable for producing sleep $(0.05>p>0.025)$.

Although more patients received atropine than scopolamine with the premedicant drugs, the distribution was the same in the three treatment groups.

Preinduction answers by the patients (Table III)

Fewer patients receiving diazepam complained of discomfort or of feeling tense, and less had complaints in general than the other two groups, but the difference was not statistically significant. Half of the patients in each group 


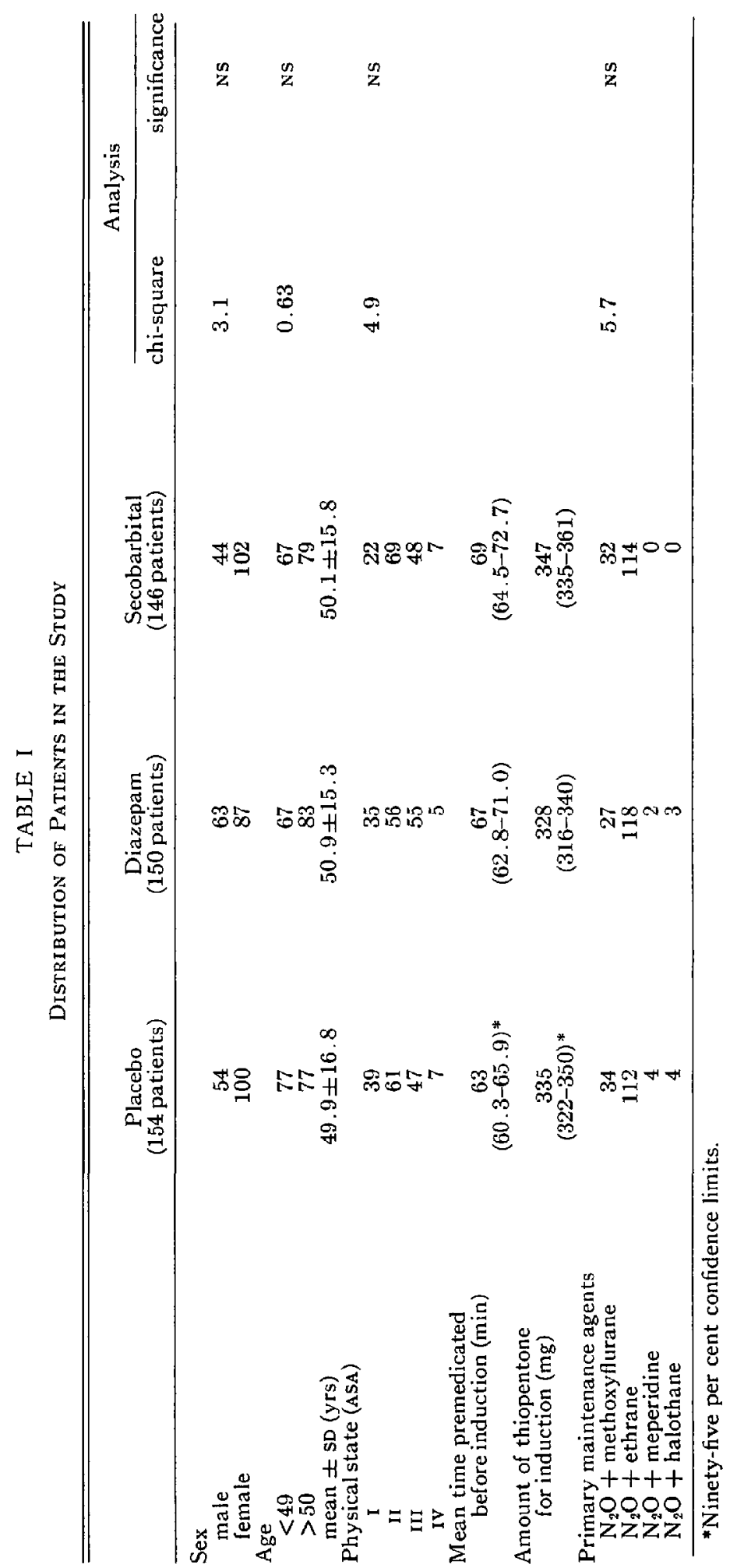


TABLE II

Use of Supplementary Medication

\begin{tabular}{|c|c|c|c|c|c|}
\hline & \multirow{2}{*}{$\begin{array}{c}\text { Placebo } \\
\text { (154 patients) } \\
\% \%\end{array}$} & \multirow{2}{*}{$\begin{array}{c}\text { Diazepam } \\
\text { (150 patients) } \\
\%\end{array}$} & \multirow{2}{*}{$\begin{array}{c}\text { Secobarbital } \\
\text { (146 patients) } \\
\%\end{array}$} & \multicolumn{2}{|c|}{ Analysis } \\
\hline & & & & chi-square & significance \\
\hline Secobarbital & 22 & 11 & 25 & 6.0 & $p=.05$ \\
\hline Atropine & 64 & 62 & 63 & & NS \\
\hline Scopolamine & 36 & 38 & 37 & & \\
\hline
\end{tabular}

TABLE III

Answers to DIRECT QUestions

\begin{tabular}{|c|c|c|c|c|c|}
\hline & \multirow{2}{*}{$\begin{array}{c}\text { Placebo } \\
\text { (154 patients) } \\
\%\end{array}$} & \multirow{2}{*}{$\begin{array}{c}\text { Diazepam } \\
\text { (150 patients) } \\
\%\end{array}$} & \multirow{2}{*}{$\begin{array}{c}\text { Secobarbital } \\
\text { (146 patients) } \\
\%\end{array}$} & \multicolumn{2}{|c|}{ Analysis } \\
\hline & & & & chi-square & significance \\
\hline Uncomfortable & 12 & 7 & 7 & 1.6 & NS \\
\hline Worried & 47 & 49 & 46 & 0.1 & NS \\
\hline Tense & 39 & 27 & 33 & 3.4 & NS \\
\hline Euphoric & 0 & 3 & 9 & 11.3 & $p<.005$ \\
\hline Sleepy & 7 & 11 & 17 & 4.9 & NS \\
\hline Nauseated & 10 & 9 & 10 & 0.1 & NS \\
\hline Vomiting & 3 & 3 & 2 & 0.5 & NS \\
\hline Tired & 32 & 31 & 32 & 0.03 & NS \\
\hline Diplopia & 2 & 0 & 2 & 2.0 & NS \\
\hline Dysphoria & 20 & 16 & 21 & 0.7 & NS \\
\hline
\end{tabular}

TABLE IV

Anaesthesiologists' Impressions of Patients' State

\begin{tabular}{lccccc}
\hline \hline & $\begin{array}{c}\text { Placebo } \\
\text { (154 patients) }\end{array}$ & $\begin{array}{c}\text { Diazepan } \\
\text { (150 patients) } \\
\%\end{array}$ & $\begin{array}{c}\text { Secobarbital } \\
(146 \text { patients })\end{array}$ & \multicolumn{2}{c}{ Analysis } \\
\hline Discomfort & 15 & 12 & 22 & 4.0 & N5 \\
Worry & 52 & 46 & 44 & 1.4 & NS \\
Tenseness & 34 & 30 & 38 & 1.3 & NS \\
Euphoria & 3 & 5 & 15 & 9.8 & $p<.01$ \\
Sleepiness & 15 & 25 & 25 & 4.3 & N5 \\
Nausea & 2 & 2 & 30 & 2.7 & NS \\
Talkativeness & 22 & 19 & 2 & 0.6 & NS \\
Lid lag & 0 & 1 & 3 & 1.5 & NS \\
Weakness & 1 & 56 & 58 & - & NS \\
Overall adequacy & 58 & 56 & & &
\end{tabular}

stated they were worried, and a significant number who received secobarbital were euphoric. Otherwise there were no appreciable differences, although the active drugs (especially secobarbital) caused a sleepy feeling more often than the placebo.

\section{Postinduction replies by the anaesthesiologist (Table IV)}

The only statistically significant difference among the replies was a higher incidence of euphoria with secobarbital. This was in agreement with the feelings expressed by the patients. The occurrence of discomfort, tenseness, and talkativeness was judged less frequent in the diazepam group, but the difference was not statistically significant. 
TABLE V

Effect of Addition of Atropine or Scopolamine to Premedication

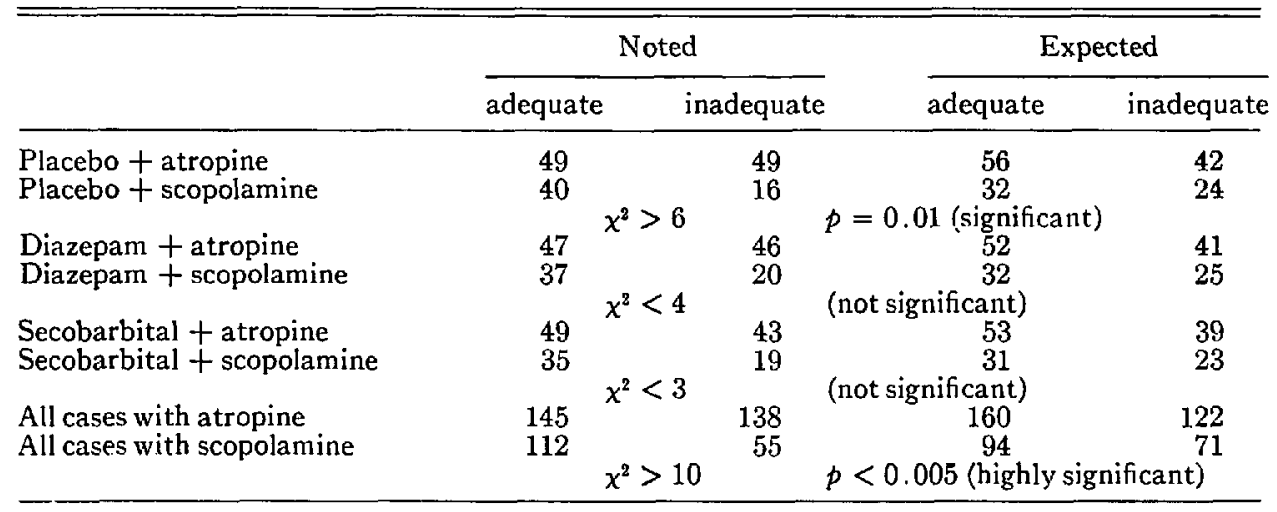

TABLE VI

Pre- and Postoperative Vital. Data

\begin{tabular}{|c|c|c|c|}
\hline & $\begin{array}{c}\text { Placebo } \\
\text { (154 patients) }\end{array}$ & $\begin{array}{c}\text { Diazepam } \\
\text { (150 patients) }\end{array}$ & $\begin{array}{c}\text { Secobarbital } \\
\text { (146 patients) }\end{array}$ \\
\hline \multicolumn{4}{|l|}{ Admission } \\
\hline BP (mean), mm Hg & $140 / 80$ & $134 / 80$ & $134 / 79$ \\
\hline $\mathrm{PR}(\operatorname{mean}) / \mathrm{min}$ & 85 & 84 & 85 \\
\hline \multicolumn{4}{|l|}{ Presedation } \\
\hline $\mathrm{BP}$ (mean), $\mathrm{mm} \mathrm{Hg}$ & $131 / 78$ & $131 / 79$ & $130 / 79$ \\
\hline PR (mean $/ \mathrm{min}$ & 82 & 81 & 81 \\
\hline \multicolumn{4}{|l|}{ Preinduction } \\
\hline BP (mean), $\mathrm{mm} \mathrm{Hg}$ & $140 / 84$ & $139 / 84$ & $139 / 85$ \\
\hline PR (mean)/min & 90 & 88 & 89 \\
\hline \multicolumn{4}{|l|}{ Hypotension $>20 \%$ after induction } \\
\hline $\begin{array}{l}\text { (patients) } \\
\text { Hypotension }>20 \% \text { after anaesthesia }\end{array}$ & 44 & 36 & 41 \\
\hline \multicolumn{4}{|l|}{ Hypotension $>20 \%$ after anaesthesia } \\
\hline Amnesia for induction period (patients) & 3 & 20 & 7 \\
\hline Shivering postanaesthesia (patients) & 12 & 11 & $\begin{array}{r}15 \\
7\end{array}$ \\
\hline Nasogastric suction used (patients) & 78 & 77 & 78 \\
\hline \multicolumn{4}{|l|}{ Nausea and/or vomiting } \\
\hline \multirow{3}{*}{$\begin{array}{l}\text { first } 24 \text { hours after anaesthesia (patients) } \\
\text { Mean delay in awakening after anaesthesia } \\
\text { (min) }\end{array}$} & 55 & 45 & 54 \\
\hline & $19.7 \pm 31$ & $4 \pm 41$ & $25.0 \pm 33$ \\
\hline & $19.7 \pm 01$ & 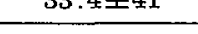 & $23.0 \pm 00$ \\
\hline
\end{tabular}

Effect of atropine or scopolamine (Table V)

As expected, scopolamine increased the incidence of adequate sedation in this patient population as a whole, and particularly in the placebo group. Overall estimation of the effectiveness of sedation by the anaesthesiologist, without weighing the individual factors checked, did not indicate a statistically significant difference in the three treatment groups.

\section{Effect on vital signs and recovery from anaesthesia (Table VI)}

None of the premedicant drugs or supplements exerted an appreciable effect on the blood pressure or pulse rate, although mean values of both were slightly higher after administration than immediately before. Amnesia was noted more often with diazepam and secobarbital than with the placebo, but the overall 
incidence was small. There was no appreciable difference in the incidence of postanaesthetic shivering or vomiting during the first 24 hours. The rate of recovery from anaesthesia was somewhat delayed by both diazepam and secobarbital.

\section{Discussion}

The clinician is well aware of the considerable difficulty in applying reliable tests of the activity of sedative drugs after short-term therapy. ${ }^{16}$ In the setting of the patient being prepared for anaesthesia and surgery, the anaesthesiologist is guided by the desire for humane care of his patients. These inherently interfere with his evaluation of new drugs. ${ }^{19}$

In this study, we felt it was necessary to provide the patient with a sound sleep the night before major surgery by providing medication with secobarbital if the patient could not sleep after the coded medication. Even though this may have interfered with the subsequent estimation of the drugs' efficacy, it nevertheless revealed that oral diazepam alone is significantly more active than secobarbital or a placebo for ensuring sleep.

The use of a supplementary dose of secobarbital as necessary may have weighted a more favourable effect in the placebo and secobarbital treatment groups at the time anaesthesia was induced, but the method used for evaluating the patients did not reveal physical or mental signs to support this. On the other hand, the use of scopolamine definitely increased the incidence of favourable responses when compared with the atropine. We have routinely observed this beneficial effect of scopolamine. ${ }^{10-19}$

The role of the dosage is possibly crucial. In the placebo group, the amount of lactose (within limits) would hardly affect the results. With secobarbital, increasing the dose to $200 \mathrm{mg}$ orally, and with diazepam, increasing the dose to $15 \mathrm{mg}$ orally, might have provided 95 per cent effectiveness for inducing sleep with either of these sedatives. Revising the dosage before induction of anaesthesia is a more complicated matter. Increasing the amount of secobarbital appreciably at this time might augment the incidence of euphoria and other undesirable psychic activity, would render the patient too drowsy - perhaps approaching basal narcosis, would increase the likelihood of respiratory and circulatory depression, especially after anaesthesia was induced, and, finally, would probably further delay recovery from anaesthesia. In the case of diazepam, increasing the oral dose in the evening might be sufficient to improve the overall effect. Since vital signs are usually affected less with diazepam than with secobarbital, an increase in dosage before anaesthesia would be less of a hazard and would be worthwhile to augment the favourable effects. However, one major drawback would be a further delay in awakening after the operation.

Although the overall evaluation of the three treatment groups did not reveal any outstanding differences by the double-blind technique of evaluation, the authors feel that diazepam did offer some improvement over placebo and secobarbital premedication both for inducing sleep at night and for reducing the tension-anxiety and discomfort that precedes major surgery, without disturbing 
vital signs. Others who have used the same method of evaluation have come to a similar conclusion. ${ }^{5,8,9}$

\section{Summary and Conclusions}

A double-blind evaluation of a placebo, diazepam, and secobarbital was carried out on 450 consenting adult patients who were scheduled for major abdominal surgery under general anaesthesia. Each patient was given a capsule orally the night before to aid sleep induction, with provision for supplementary medication with secobarbital if sleep did not occur. Approximately one hour before surgery the following morning, a staff physician administered a solution of the same compound intramuscularly along with atropine or with scopolamine. Relevant data were collected concurrently from the patient's record, anaesthesia chart, and by direct questions to the patient prior to induction of anaesthesia, and to the attending anaesthesiologist after induction of anaesthesia by a registered nurse experienced in this work. When the study was completed, the data were punched on IBM cards, tabulated, and analysed statistically by the chisquare test, following which the code was revealed.

Analysis of the data showed that the three groups were reliably comparable. None of the treatments caused untoward changes in vital signs, and no adverse reactions were observed. The overall effect of the response to treatment may have been influenced by the supplementary dose of secobarbital, but the diazepam group definitely had a higher incidence of evening sleep induction. Diazepam appeared to reduce tension-anxiety and discomfort more frequently than the placebo or secobarbital, although the difference was not statistically significant. Dysphoria and undesirable psychic stimulation (euphoria) occurred significantly more often with secobarbital. The use of scopolamine definitely augmented the incidence of a favourable response to premedication, especially when a placebo treatment was used, as compared with the groups that received atropine.

The anaesthesiologist was not usually able to distinguish the treatment given, especially when the overall effect was judged inadequate.

The authors believe that diazepam is more effective than was revealed objectively in this study and, for the type of cases employed, a higher dose (15 mg) would more clearly reveal its efficacy in premedication.

\section{RÉSUMÉ}

On a comparé l'action du placebo, du diazépam ( $10 \mathrm{mg}$ ) et du sécobarbital (100 mg) chez 450 malades adultes ayant subi des opérations abdominales majeures sous anesthésie générale. La veille de lintervention, chaque malade recevait une prémédication per os; une dose supplémentaire de sécobarbital était prescrite pour les malades qui faisaient de l'insomnie. Le lendemain, environ une heure avant l'opération, un médecin injectait par voie intra-musculaire une dose du même médicament additionné d'atropine ou de scopolamine. Tout renseignement acquis auprès du malade, soit par l'anesthésiologiste, soit par 
l'infirmière était soumis à l'analyse statistique par ordinateur IBM. Alors seulement on dévoilait le code du double inconnu.

L'analyse a démontré que les groupes de malades étaient bien comparables et qu'il n'y avait pas de changements de l'homéostase.

Le groupe recevant le diazépam s'endormait mieux la nuit précédant l'opération, mème en considérant que la réponse générale pouvait être quelque peu modifiée par les doses supplémentaires de sécobarbital. L'état émotif et le confort des malades recevant le diazépam étaient meilleurs que chez les autres malades, même si cette différence n'était pas significative du point de vue statistique. Le sécobarbital produisait une dysphorie plus souvent que les autres médicaments. La scopolamine était supérieure à l'atropine surtout chez les malades n'ayant reçu qu'un placebo.

D’après notre étude, nous pensons que le diazépam a donné des résultats nettement supérieurs, et que l'emploi d'une posologie plus poussée ( $15 \mathrm{mg}$ ) améliorera son efficacité comme médication pré-opératoire.

\section{ACKNOWLEDGMENTS}

The authors are indebted to Doctor Stephen N. Preston of Hoffmann-La Roche Incorporated for supplying the coded drug materials and for a grant-in-aid. This study was also supported by the Division of Research Facilities and Resources of the National Institutes of Health through grant FR 00353.

\section{REFERENCES}

1. Dobkin, A. B. \& Su, J. P-G. Newer Anesthetics and Their Uses. Clin. Pharmacol. \& Therap. 7: 648 (1966).

2. MCClish, A. Diazepam as an Intravenous Induction Agent for General Anaesthesia. Canad. Anaesth. Soc. J. 13: 562 (1966).

3. Nutter, D. O. \& Massumi, R. A. Diazepam in Cardioversion. New England J. Med. 273: 650 (1965).

4. Fox, G. S.; Wynands, J. E.; \& Bhambhani, M. A Clinical Comparison of Diazepam and Thiopentone as Induction Agents to General Anaesthesia. Canad. Anaesth. Soc. J. 15: 281 (1968).

5. Romagnoli, A.; Curson, S.; \& Cohen, M. The Use of Diazepam in Paediatric Premedication. Canad. Anaesth. Soc. J. 15: 603 (1968).

6. Dechêne, J-P. \& Desrosiers, R. Diazepam in Pulmonary Surgery. Canad. Anaesth. Soc. J. 16: $162(1969)$.

7. Straja, A. M.; Munro, D. D.; \& Gribert, R. G. B. Bronchoscopy with the Aid of Diazepam. Canad. Anaesth. Soc. J. 16:241 (1969).

8. Brandt, A. L. \& Oakes, F. D. Preanesthesia Medication: Double Blind Study of a New Drug, Diazepam. Anesth. \& Analg. 44: 125 (1965).

9. Tonnetta, F. J. Diazepam as Preanesthetic Medication: A Double-Blind Study. Anesth. \& Analg. 44: 449 (1965).

10. Bozza Maruubini, M. \& Tretola, L. Diazepam as a Pre-operative Tranquilizer in Neuro-Anaesthesia: A Preliminary Note. Brit. J. Anaes. 37: 934 (1965).

11. Conmter, A.; Goyette, M.; Ké́ri-Szántó, M.; \& Rheault, J. A Comparison of the Action of Meperidine and Diazepam in Anaesthetic Medication, Canad, Anaesth. Soc. J. 13: 368 (1966).

12. Steen, S. N.; Weitzner, S. W.; Amaha, K; \& Martinez, L-R. The Effect of Diazepam on the Respiratory Response to Carbon Dioxide. Canad. Anaesth. Soc. J. 13: 374 (1966). 
13. Randall, L. O.; Schallek, W; Heise, G. A.; Keith, E. F.; \& Bagdon, R. E. The Psychosedative Properties of Methaminodiazepoxide. J. Pharmacol. Exper. Therap. 129: 163 (1960).

14. Randall, L. O. et al. Pharmacological and Clinical Studies on Valium: A New Psychotherapeutic Agent of the Benzodiazepine Class. Curr. Therap. Res. 3: 405 (1961).

15. Himwich, H. E.; Mormlo, A.; \& Sterner, W. G. Drugs Affecting Rhinencephalic Structures. J. Neuropsychiat. 3: Suppl. 1, 15 (1962).

16. Dobkin, A. B.; Wyant, G. M.; \& DYck, F. Clinical Evaluation of Methyprylon (Noludar(8) as a Preanaesthetic Sedative Hypnotic. Canad. Anaesth. Soc. J. 4: 27 (1957).

17. Dobkin, A. B. \& Purkin, N. Double Blind Study of Phenothiazines Used in Preanaesthetic Medication. Canad. Anaesth. Soc. J. 7: 158 (1960).

18. Dobkin, A. B.; Israel, J. S.; \& BYLES, P. H. Double Blind Study of Methotrimeprazine, Morphine and Meperidine for Preanesthetic Medication. Anesth. \& Analg. 44: 510 (1965).

19. Dobkin, A. B.; Malik, K.; \& Israel, J. S. Double-Blind Study of Hydroxyzine, Promethazine, Secobarbital and a Placebo for Preanaesthetic Medication. Canad. Anaesth. Soc. J. 12: 499 (1965). 